\title{
Determinants of Acute Respiratory Infection in Children Under Five in Simalingkar, Medan, North Sumatera
}

\author{
Lasma Maria'), Maestro Simanjuntak²), Thomas Silangit3), \\ Jekson Martiar Siahaan4)
}

\author{
1)Faculty of Medicine, Universitas Methodist Indonesia, Medan \\ 2)Department of Public Health, Faculty of Medicine, Universitas Methodist Indonesia, Medan \\ 3)Department of Clinical Pathology, Faculty of Medicine, Universitas Methodist Indonesia, Medan \\ 4)Department of Physiology, Faculty of Medicine, Universitas Methodist Indonesia, Medan
}

\section{ABSTRACT}

Background: Acute Respiratory Infection (ARI) is still one of the health problems in developed and developing countries including Indonesia. ARI is the most common disease in outpatients in North Sumatra, especially in Medan. This study aims to find out about the factors that influence ARI in toddlers in Simalingkar Health Center Medan, including nutritional status, birth weight, history of immunization, exclusive breastfeeding, and parental smoking status.

Subjects and Method: This was a cross sectional study. The sample used was all toddlers who came to the Simalingkar health center, amounting to 100 people. Data collection was carried out using interviews and analysis was carried out using bivariate and multivariate with multiple logistic regression.
Results: The results showed that there was a significant influence between nutritional status, exclusive breastfeeding and parental smoking status with the incidence of ARI in infants.

Conclusion: The results showed that there was a significant influence between nutritional status, exclusive breastfeeding and parental smoking status with the incidence of ARI in infants.

Keywords: acute respiratory infection, children under five

\section{Correspondence:}

Lasma Maria. Faculty of Medicine, Universitas Methodist Indonesia, Medan Email: lasmamaria12@gmail.com.

Cite this as:

Maria L, Simanjuntak Maestro, Silangit, Siahaan JM (2020). Determinants of Acute Respiratory Infection in Children under Five in Simalingkar, Medan, North Sumatera. J Epidemiol Public Healt, 5(1): 26-30. https://doi.org/10.26911/jepublichealth.2020.05.01.03

cc) (i) (2) Journal of Epidemiology and Public Health is licensed under a Creative Commons C. ${ }_{\text {EY NC SA }}$ Attribution-NonCommercial-ShareAlike 4.o International License.

\section{BACKGROUND}

Acute Respiratory Infection (ARI) is still one of the health problems in developed and developing countries including Indonesia. This is because there are still many morbidity and mortality rates due to ARI, especially those that occur in infants. ARI is the main cause of infant mortality (Ministry of Health, 2011).

According to the World Health Organization (WHO), in 2011, ARI sufferers numbered 48,325 children and estimates that in developing countries are around 30-70 times higher than in developed countries and it is estimated that $20 \%$ of babies born in developing countries fail to reach the age of 5 years and $25^{-} 30 \%$ of child deaths are caused by ARI (Ministry of Health, 2010).

ARI ranks first among the illnesses suffered in the group of infants and toddlers in Indonesia (MoH, 2011). The five provinces in Indonesia with the highest ARI are East Nusa Tenggara, Papua, Aceh, West Nusa Tenggara and East Java (Ministry of Health, 2010). The pattern of outpatient disease in North 
Sumatra Community Health Center (Puskesmas) especially Medan in 2016, ARI was ranked top of 40.23\% (North Sumatra Department of Health, 2017).

ARI can be caused by three factors, namely individual child factors, behavioral factors and environmental factors. Individual child factors include: child's age, sex, birth weight, nutritional status, vitamin A, exclusive breastfeeding and immunization status. Behavioral factors include the level of knowledge, economic status, behavioral prevention and prevention of ARI in infants or the active role of family/ community in dealing with ARI. Environmental factors include: air pollution in the home (cigarette smoke and smoke from burning fuel for cooking with high concentrations), house ventilation and occupancy density (Wahyono et al., 2008).

The number of risk factors for increased ARI in an area becomes the basis of study to find out the factors that influence ARI in children under five in Simalingkar Health Center Medan in 2019. This study aims to find out about the factors that influence the factors that influence ARI in toddlers in Pusaling Simalingkar Medan.

\section{SUBJECTS AND METHOD}

\section{Study Design}

This was a cross-sectional study conducted at the Simalingkar health center, Medan, North Sumatra, in April 2019.

\section{Population and Sample}

The sample is 100 toddlers, consisting of 63 toddlers with ISPA and 37 toddlers without ISPA, selected by purposive sampling.

\section{Study Variables}

The dependent variable is the ARI event. The independent variables are toddler nutritional status, exclusive breastfeeding, and parental smoking status.

\section{Data Analysis}

The data were analyzed with multiple logistic regression.

\section{RESULTS}

\section{Bivariate analysis}

Table 1 shows the results of cross tabulation of factors related to ARI events. Table 1 shows that toddlers with underweight (81.25\%) had a higher percentage of ARI than toddlers with sufficient nutritional status (23.08\%). Table 1 shows that toddlers who did not receive exclusive breastfeeding had a higher percentage of experiencing ARI $(72.60 \%)$ than toddlers who did not receive exclusive breastfeeding (37.04\%).

Table 2 shows the results of multiple logistic regression factors related to ARI events. Table 2 shows that poor nutritional status $(b=1.20 ; 95 \% \mathrm{CI}=1.68$ to $6.51 ; \mathrm{p}$ $<0.001)$, not exclusive breastfeeding $(\mathrm{b}=$ 1.68; $95 \% \mathrm{CI}=1.53$ to $18.92 ; \mathrm{p}=0.002$ ), and parents smoke $(b=2.29 ; 95 \% \mathrm{CI}=3.10$ to 31.20; $\mathrm{p}<0.001$ ) increases the risk of ARI.

Table 1. Cross tabulation of factors related to ARI events

\begin{tabular}{|c|c|c|c|c|c|c|c|}
\hline \multirow{3}{*}{ Independent Variable } & \multicolumn{4}{|c|}{ ARI event } & \multirow{2}{*}{\multicolumn{2}{|c|}{ Total }} & \multirow{3}{*}{$\mathbf{p}$} \\
\hline & \multicolumn{2}{|c|}{ ISPA } & \multicolumn{2}{|c|}{ Not ISPA } & & & \\
\hline & $\mathbf{n}$ & $\%$ & $\mathbf{n}$ & $\%$ & $\mathbf{n}$ & $\%$ & \\
\hline \multicolumn{8}{|l|}{ Nutritional Status } \\
\hline Poor & 39 & 81.25 & 9 & 18.75 & 48 & 100 & $<0.001$ \\
\hline Over & 18 & 69.23 & 8 & 30.77 & 26 & 100 & \\
\hline Adequate & 6 & 23.08 & 20 & 76.92 & 26 & 100 & \\
\hline \multicolumn{8}{|l|}{ Birth Weight } \\
\hline$<2500 \mathrm{~g}$ & 14 & 66.67 & 7 & 33.33 & 21 & 100 & 0.891 \\
\hline $\begin{array}{l}\geq 2500 \mathrm{~g} \\
\text { Immunization History }\end{array}$ & 49 & 62.03 & 30 & 37.97 & 79 & 100 & \\
\hline Incomplete & 5 & 62.50 & 3 & 37.50 & 8 & 100 & 1.000 \\
\hline
\end{tabular}


Maria et al./ Determinants of Acute Respiratory Infection in Children

\begin{tabular}{|c|c|c|c|c|c|c|c|}
\hline \multirow{3}{*}{ Independent Variable } & \multicolumn{4}{|c|}{ ARI event } & \multirow{2}{*}{\multicolumn{2}{|c|}{ Total }} & \multirow{3}{*}{$\mathbf{p}$} \\
\hline & \multicolumn{2}{|c|}{ ISPA } & \multicolumn{2}{|c|}{ Not ISPA } & & & \\
\hline & $\mathbf{n}$ & $\%$ & $\mathbf{n}$ & $\%$ & $\mathbf{n}$ & $\%$ & \\
\hline \multicolumn{8}{|l|}{ Nutritional Status } \\
\hline $\begin{array}{l}\text { Complete } \\
\text { Exclusive Breastfeeding }\end{array}$ & 58 & 63.04 & 34 & 36.96 & 92 & 100 & \\
\hline No & 53 & 72.60 & 20 & 27.40 & 73 & 100 & 0.002 \\
\hline Yes & 10 & 37.04 & 17 & 62.96 & 27 & 100 & \\
\hline \multicolumn{8}{|l|}{ Parental Smoking Status } \\
\hline Yes & 54 & 79.41 & 14 & 20.59 & 68 & 100 & $<0.001$ \\
\hline No & 9 & 28.13 & 23 & 71.87 & 32 & 100 & \\
\hline
\end{tabular}

Table 2. Results of multiple logistic regression factors related to ARI events

\begin{tabular}{|c|c|c|c|c|}
\hline \multirow{2}{*}{ Independent Variable } & \multirow{2}{*}{ b } & \multicolumn{2}{|c|}{$95 \%$ CI } & \multirow[b]{2}{*}{$\mathbf{p}$} \\
\hline & & Lower limit & Upper limit & \\
\hline Constant & -2.83 & & & $<0.001$ \\
\hline Nutritional Status (poor) & 1.20 & 1.68 & 6.51 & $<0.001$ \\
\hline $\begin{array}{l}\text { Not exclusive } \\
\text { breastfeeding }\end{array}$ & 1.68 & 1.53 & 18.92 & 0.002 \\
\hline Smoking parents & 2.29 & 3.10 & 31.20 & $<0.001$ \\
\hline
\end{tabular}

\section{DISCUSSION \\ 1. The effect of nutrition status and the risk of ARI}

The results of this study indicate that there is a positive and statistically significant relationship between poor nutritional status and the incidence of ARI. The results of this study are consistent with Pajeriaty (2018), at Makassar District Hospital which states that there is a relationship between nutritional status and ARI events. Similar results were also shown by Alemayehu et al. (2019).

Malnutrition causes abnormalities in the airways so that it disrupts the physiological processes of the airways in terms of protection against disease agents. In children with abnormal nutritional status, the physiological process will not run properly, so that the disease agent that should be released by the body into the airways to the lungs (Bates, 2013).

\section{The effect of birth weight and the risk of ARI}

The results of bivariate analysis showed that birth weight $<2,500 \mathrm{~g}$ and $\geq 2,500 \mathrm{~g}$ had the same risk for experiencing ARI $(p=0.891)$.
Toddlers born with low birth weight have a greater risk for suffering from ARI. Toddlers with low birth weight have immature respiratory organs which cause inadequate lung development, respiratory muscles are still weak, and the respiratory center is not yet developed. Lack of surfactant substances can reduce tension on the lung surface (Ibrahim, 2011).

\section{The effect of exclusive breastfeeding and the risk of ARI}

The results of this study indicate that more toddlers suffering from ARI in Simalingkar Health Center in Medan are not given exclusive breastfeeding compared to those given exclusive breastfeeding. The results of this study are in accordance with Rahman et al. (2015) which states that the proportion of toddlers who are not given exclusive breastfeeding is greater in the proportion of toddlers who experience ISPA. Tallo et al. (2012) and Tromp et al. (2017) showed that exclusive breastfeeding decreases the risk of ARI exposure to infants.

Breast milk contains a variety of antiinfectious substances that can protect child- 
ren against infection. The best breast milk is obtained in the first week of lactation where ASI contains many protective cells such as leukocytes consisting of macrophages, Tlymphocytes and B lymphocytes. Lymphocytes themselves have the function to synthesize IgA antibodies. IgA can protect the respiretory tract membranes from infection because IgA contains antibodies against respiratory and digestive virus (Medhyna, 2017).

\section{The effect of parental smoking status and the risk of ARI}

The results of this study indicate that toddlers whose parents have more smoking status experience ARI than those who do not smoke. Exposure to parental cigarette smoke to ARI in infants due to exposure to cigarette smoke for $\geq 30$ minutes can cause damage to endothelial cells and blood clotting cells and cause constriction and stiffness of blood vessels (Aryani et al., 2016).

Smoke released by active smokers contains carbon monoxide 5 times greater, tar and nicotine 3 times, ammonia 46 times, nickel 3 times, nitrosamine as a cause of cancer levels reaches 50 times greater than the smoke inhaled by these active smokers (WHO, 2008).

Trisnawati et al. (2012) states that if infants continue to be exposed to cigarette smoke, it can cause respiratory problems, especially facilitating the emergence of acute respiratory infections and lung disorders in the long term as adults.

\section{REFERENCE}

Alemayehu S, Kidanu K, Kahsay T, Kassa M (2019). Risk factors of acute respiratory infections among under five children attending public hospitals in southern Tigray, Ethiopia, 2016/2017. BMC Pediatr. 19: 380. https://doi.org/10.1186/s12887-019-1767-1.

Aryani N, Syapitri H (2016). Hubungan kebiasaan merokok anggota keluarga di dalam rumah dengan ISPA pada balita di Puskesmas Helvetia Tahun 2016 (The effect of smoking habits of family members at home with ARI in infants at Helvetia Health Center in 2016). Jurnal Kesehatan Masyarakat dan Lingkungan Hidup. 3(1): 29-37. Retrieved from http://e-journal.sari-mutiara.ac.id/index.php/Kesehatan_Masyarakat/article/view/593.

Bates M, Chandyo RK, Valentiner-Branth P, Pokhrel AK, Mathisen M, Basnet S, Shrestha PS, Strand TA, Smith KR (2013). Acute lower respiratory infection in childhood and household fuel use in Bakhtapur, Nepal. Environmental Health Perspectiv. 121(5): 637-42. doi: 10.1289/ehp.1205491

Department of Health (2011). Pedoman pengendalian infeksi saluran pernapasan akut (Guidelines for controlling acute respiratory infections). Direktorat Jenderal Pengendalian Penyakit dan Penyehatan Lingkungan.

Medhyna V (2017). Faktor yang mempengaruhi kejadian ISPA pada bayi usia 4 sampai 6 bulan (Factors affecting the incidence of ARI in infants aged 4 to 6 months). Jurnal human care. 2(1).

Ministry of Health (2010). Pedoman pengendalian infeksi saluran pernafasan akut (Guidelines for controlling acute respiratory infections).

Pajeriaty (2018). Faktor yang berhubungan dengan kejadian infeksi saluran pernapasan akut (ISPA) pada pasien anak balita (1-5 tahun) di RSUD Haji Makassar (Factors related to the incidence of acute respiratory infections (ARI) in patients under five (1-5 years) at Haji Makassar Hospital). Jurnal Ilmiah Kesehatan Diagnosis. 12(5): 512. Rahman A, Nur FA (2015). Hubungan pemberian ASI eksklusif dengan kejadian penyakit infeksi saluran pernafasan 
akut pada anak balita di wilayah kerja Puskesmas Managaisaki (The relationship of exclusive breastfeeding with the incidence of acute respiratory tract infections in children under five in the working area of Managaisaki Health Center). Jurnal Kesehatan Tadulako. 1(1).

Tallo KT, Suandi IKG, Wandita S (2012). The effect of exclusive breastfeeding on reducing acute respiratory infections in low birth weight infants. 54(2): 229. https://doi.org/10.14238-

/pi52.4.2012.229-32.

Trisnawati Y, Juwarni (2013). Hubungan perilaku merokok orang tua dengan kejadian ISPA pada balita di wilayah kerja Puskesmas Rembang Kabupaten Purbalingga 2012 (The effect of smoking behavior of parents with ARI events in infants in the working area of Rembang Public Health Center in Purbalingga Regency 2012). Jurnal Kesmasindo. 6(1): 35-42.

Tromp I, Kiefte-de Jong J, Raat H, Jaddoe V, Franco O, Hofman A, de Jongste J,
Moll H (2017). Breastfeeding and the risk of respiratory tract infections after infancy: The Generation R Study. 12(2): eo172763. https://dx.doi.org/10.1371\%2Fjournal.pone.0172763

Wahyono D, Hapsari I, Astuti IWB (2008). Pola pengobatan infeksi saluran pernapasan akut anak usia bawah lima tahun (balita) rawat jalan di Puskesmas I Purwareja Klampok Kabupaten Banjarnegara tahun 2004 (The pattern of treatment of acute respiratory tract infections of children under five years old (toddlers) outpatient in Puskesmas I Purwareja Klampok Banjarnegara District in 2004). Majalah Farmasi Indonesia. 19(1).

World Health Organization (2008). Pencegahan dan Pengendalian ISPA di Fasilitas Pelayanan Kesehatan (Prevention and Control of ARI in Health Care Facilities). Retrieved from http://www.who.int/csr/resources/publications/AMpandemicbahasa.pdf. 